\title{
石垣島宮良川沖沿岸海域表面水中のケイ酸塩, リン酸塩，及び溶存カドミウムについて
}

\author{
阿部和雄* ・福岡弘紀
}

\author{
西海区水産研究所石垣支所 $\overline{7} 907-0451$ 沖縄県石垣市字桴海大田 148-446
}

\begin{abstract}
要旨 沖縄県石垣島宮良湾沖合域（岸からの距離約 $1800,2700,3900 \mathrm{~m}$ ）及び宮良川河口において, 2006 年 8 月から 2007 年 12 月まで一月に一回程度の間隔で表面水中のケイ酸塩, リン酸塩, 及び溶存力 ドミウム濃度を定量した。塩分・水温から見た沖合域の海域特性は, 一般に宮良川からの淡水流出及び気 温変動の影響を受け，12-5 月の低水温・高塩分傾向，6-10月の高水温・広範囲な塩分分布，及び 11 月の 中間的な傾向を示す周年変動が認められた。沖合域で観測されたケイ酸塩, リン酸塩, 及び溶存カドミウ 厶の濃度変動は周年を通して顕著ではなく，最大でそれぞれ $7 \mu \mathrm{M}, \quad 0.13 \mu \mathrm{M}, \quad 32 \mathrm{pM}$ 程度であった。この 調査海域はサンゴ礁に隣接しており，一部の海水は礁内の海水交換に伴い外洋水として礁内へ流入する。 調査海域で得られたリン酸塩やカドミウム濃度は現在のところ富栄養や重金属污染等の兆候はなく, 実際 の栄養塩とサンゴ生育の関係等から判断すると, 隣接するサンゴ礁生態系への当海域からの富栄養等の影 響は小さいものと考えられる。
\end{abstract}

キーワード ケイ酸塩, リン酸塩, 溶存カドミウム, 沿岸域, 石垣島

\section{はじめに}

石垣島は琉球列島南西部に位置し（総面積約 $\left.229 \mathrm{~km}^{2}\right)$, 島の周囲はいわゆる裾礁型のサンゴ礁が 発達している (Fig. 1)。年間の平均気温は $24^{\circ} \mathrm{C}$, 降水量は $2,000 \mathrm{~mm}$ 程度である。島のほぼ中央部に 起源を持つ宮良川は，石垣島を南北に流れる流域面 積 $35.40 \mathrm{~km}^{2}$, 総延長 $12 \mathrm{~km}$ の 2 級河川である。降 雨時には比較的多量の降水が沿岸海域へと流出する が, この際流域の田畑から土壌が赤土として沿岸域 へ輸送され，サンゴやサンゴ礁域を含む沿岸生態系 への影響が懸念されている（大見謝 1996; 仲宗根ら 1998）。一般にサンゴ礁域では礁内の海水交換に 伴って, 近接する海域の外洋水が礁内へ流入する (Nakamori et al. 1992; 灘岡ら 1999; 灘岡 2001)。サ ンゴ礁に隣接する沿岸海域の環境特性の把握は, 外 洋水が礁内へ流入した後のサンゴ礁生態系への影響 を評価する上でも重要である。本稿はサンゴ礁に隣

\section{*連絡著者}

E-mail: abek@fra.affrc.go.jp

担当編集者: 山野博哉（環境・保全分野）
接する沿岸海域として石垣島宮良川沖を設定し，現 場の環境把握調查の一環として栄養塩であるケイ酸 塩, リン酸塩, 及び重金属の一つであるカドミウム について，それらの濃度レベルや河川との関連につ いて得られた知見の報告である。一般にケイ酸塩や リン酸塩はサンゴ礁生態系を含む生物生産には必須 の成分であると考えられるが，リン酸塩による富栄 養状態下ではサンゴ礁の衰退等負の影響が懸念され ている(Coles and Ruddy 1995)。また，カドミウム 等の重金属については Reichelt-Brushett and Harrison（2005）が報告しているように, サンゴの受精 に影響を及ぼす物質として知られている。 ReicheltBrushett and Harrison（2005）が行った実験では, 実際に受精に影響を与えるカドミウム濃度は $10 \mu \mathrm{M}$ 程度と通常の污染を受けていない海域で観測される 值よりもかなり高濃度ではある。しかしながら, 将 来に起こり得る海洋污染の実態評価, 及びサンゴ礁 を含む亜熱帯沿岸海域の生態系保全の立場からも, 現時点での污染状況を含めた動態把握は重要である と考えられる。 


\section{調査及び試料の分析}

調査は Fig. 1 に示す石垣島宮良湾沖合域の 3 点 において，2006 年 8 月より 2007 年 12 月まで概ね 一月に一度程度の頻度で西海区水産研究所石垣支所 の調查艇「やえやま」(4.9トン) により行った。調 查点は沖合から河口に向け設定した St.1 $\left(24^{\circ} 19.0\right.$ N, $124^{\circ} 13.0$ E), St.2 (24⒚7 N, $124^{\circ} 13.0$ E), 及び St.3（24 $20.2 \mathrm{~N}, 124^{\circ} 13.0 \mathrm{E} ）$ の 3 点である。 水深はそれぞれ $100,50,20 \mathrm{~m}$ 程度で，岸からはそ れぞれ約 3900，2700， $1800 \mathrm{~m}$ 程沖合に位置する。 これらの調査点に打ける表面海水を, 酸洗いした 10 リットルポリバケツを用いて採取し, 試水中の 塩分, ケイ酸塩, リン酸塩, 及び溶存カドミウムを 定量した。また, 水温及び塩分の鉛直分布はアレッ ク電子製のメモリー式多項目水質計（クロロテック ACL208）を用いて測定した。これらの沖合域に加 えて，宮良川河口（Fig. 1右パネル内白丸）におい ても同様に採水を行った。実験室に試料を持ち帰 り，ケイ酸塩およびリン酸塩は試水を $0.4 \mu \mathrm{m}$ ヌク レポアーフィルターで滤過後, それぞれモリブデン イエロー，モリブデンブルー法による比色分析によ り定量した (Strickland and Parsons 1972)。溶存 カドミウムは栄養塩分析と同様に $0.4 \mu \mathrm{m}$ ヌクレポ アーフィルターで滤過後, Boyle and Edmond (1977)
の分析法を若干改良し, 無煙原子吸光分光光度計 （日立Z-8270）により定量を行った（Abe 2001）。 なお, 分析精度はケイ酸塩, リン酸塩, 溶存カドミ ウムにつきそれぞれ，2.23 $\mu \mathrm{M}$ で $35.3 \%(n=7)$, $0.053 \mu \mathrm{M}$ で $38.9 \%(n=8), 33.7 \mathrm{pM}$ で $27.2 \% \quad(n=6)$ 程度である。検出限界は空試験值標準偏差の 2 倍と し, ケイ酸塩で $0.96 \mu \mathrm{M}$, リン酸塩で $0.015 \mu \mathrm{M}$, 溶 存カドミウムは $5 \mathrm{pM}$ である。さらに, 表面水の塩 分測定を鶴見精器デジオート 3-Gにより行った。

\section{結果}

クロロテックにより 2007 年 1 月から 12 月に得ら れた沖合域における水温及び同日の塩分の鉛直分布 をそれぞれ Fig. 2 と Fig. 3 に示した。これらの図 では代表的なパターンとして $1,4 ， 6 ， 7 ， 9 ， 10$, 11 月の結果を太線で示した。また，その他の 2,3 , 5，8，12月の結果を細線で示した。なお，St. 1 に おける 7 月は欠測のため観測值はない。

1 月の水温・塩分は概ね各観測点で冬季の鉛直混 合を反映しほぼ鉛直的に均一であった。 4 月になる と両成分共に鉛直的に均一を保ったままで水温は $1^{\circ} \mathrm{C}$ 程低下, 塩分は 0.1 から 0.2 程度高めに推移し た。6月になると表面付近から急激な水温の上昇が

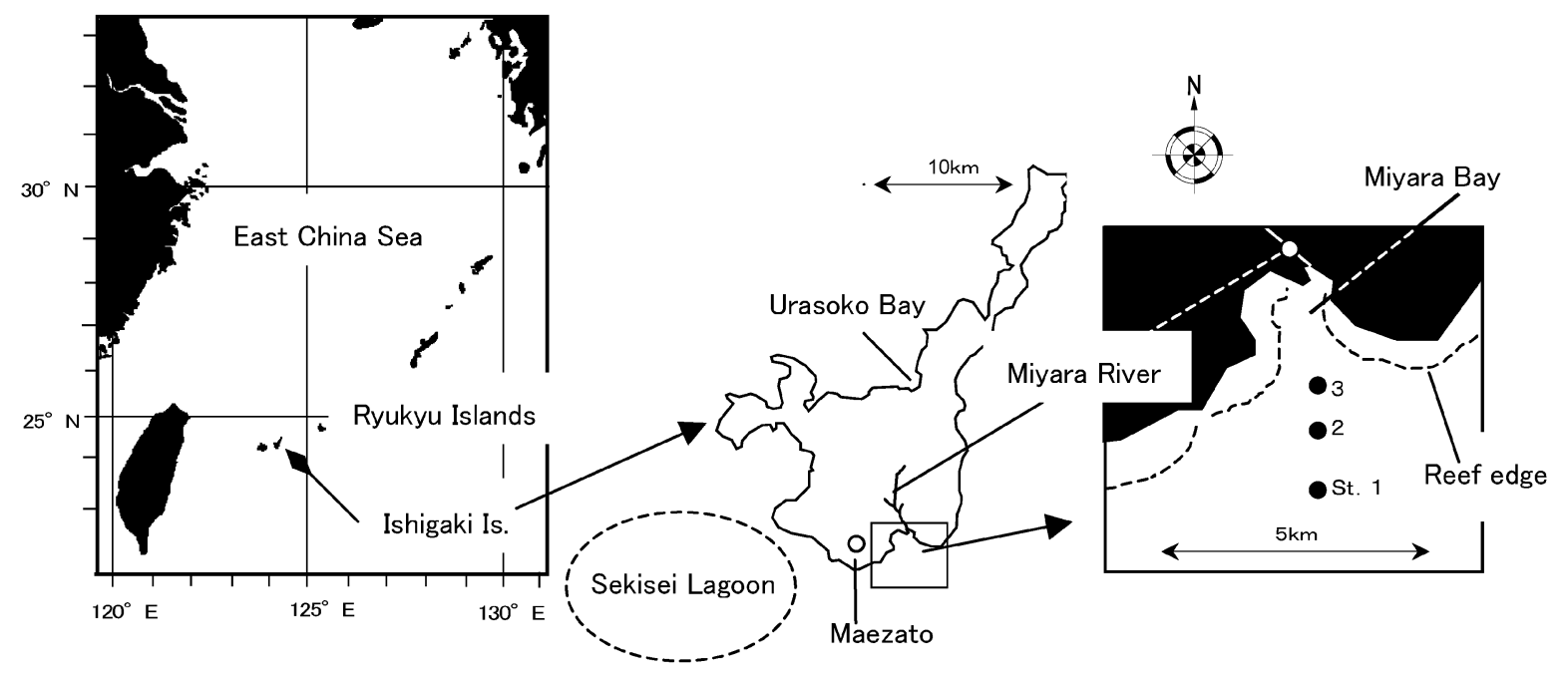

図 1 サンプリング地点。右側の図に沖合域の調査点（1，2，3）と河口域の調査点をそれぞれ 黒丸と白丸で示す

Fig. 1 Map showing the sampling sites. In the panel on the right, the sampling stations (Sts. 1,2 , and 3 ) at the offshore and river mouth sites are shown as closed circles and a filled white circle, respectively 

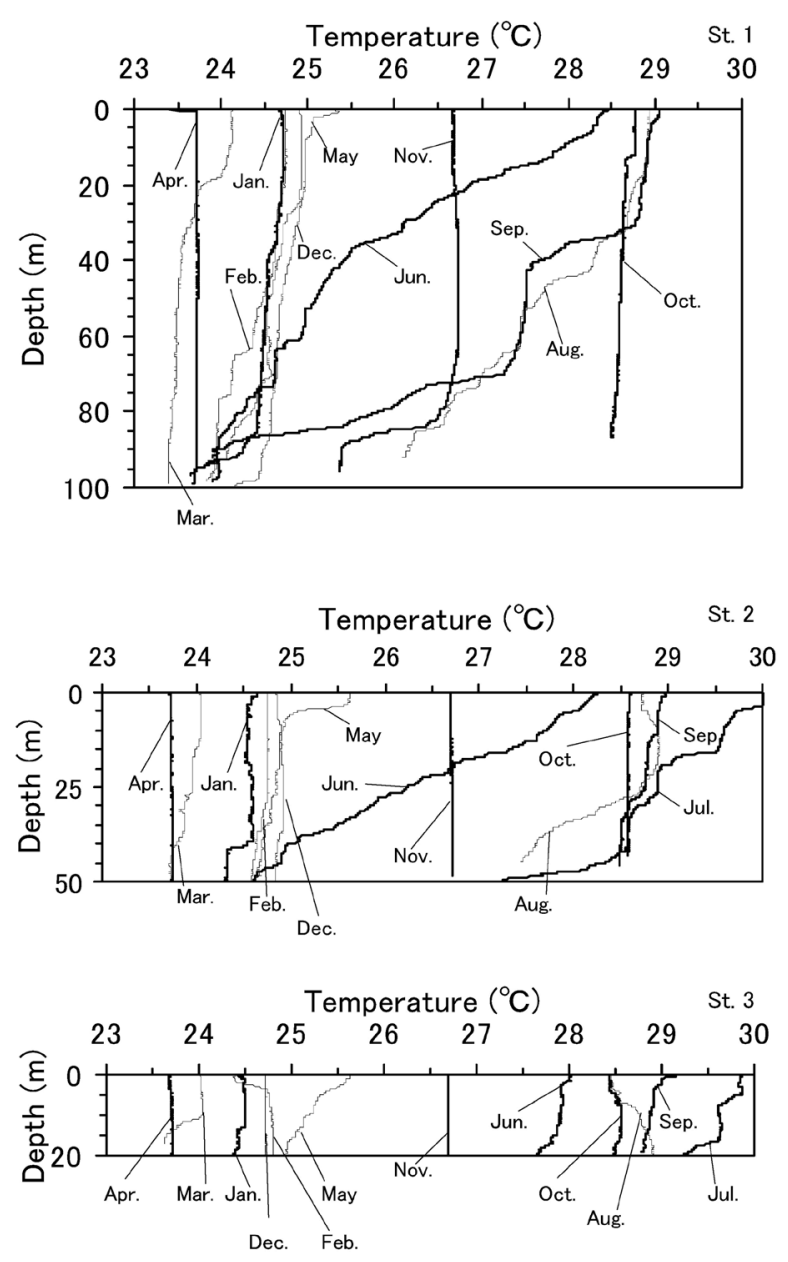

図 2 沖合域の調查点 $1,2,3$ に扔ける水温の鉛直 プロファイル

Fig. 2 Vertical profiles of the water temperature at three offshore sites, i.e., Sts. 1, 2, and 3

始まり大きな温度勾配が観測された。塩分は 4 月と ほほ同じ值で底層まで均一ではあるが, 各観測点で 表層付近より減少傾向が見られる。7月ではでさら に全体的に水温の上昇が観測され，表面では 6 月よ りも $2^{\circ} \mathrm{C}$ 程度高くなった（St. 2, 3)。9月の水温は 比較的高レベルを保ったままではあるが，表面で $1^{\circ} \mathrm{C}$ 程低下すると共に表層付近から鉛直混合開始の 兆候が見られる。10月では 9 月よりも塩分は 0.2 程 度低下し, 水温・塩分共に再び鉛直的に均一な傾向 が観測された。11月の観測では 10 月よりも水温で $2{ }^{\circ} \mathrm{C}$ 程の低下及び塩分で 0.1 程度高塩分側へと移行 した。また, 細線で示した月の鉛直分布は概ね上述 した水温・塩分変動パターンに付随する傾向を示し たが，8月には表層付近の低塩分が 3 観測点で観測
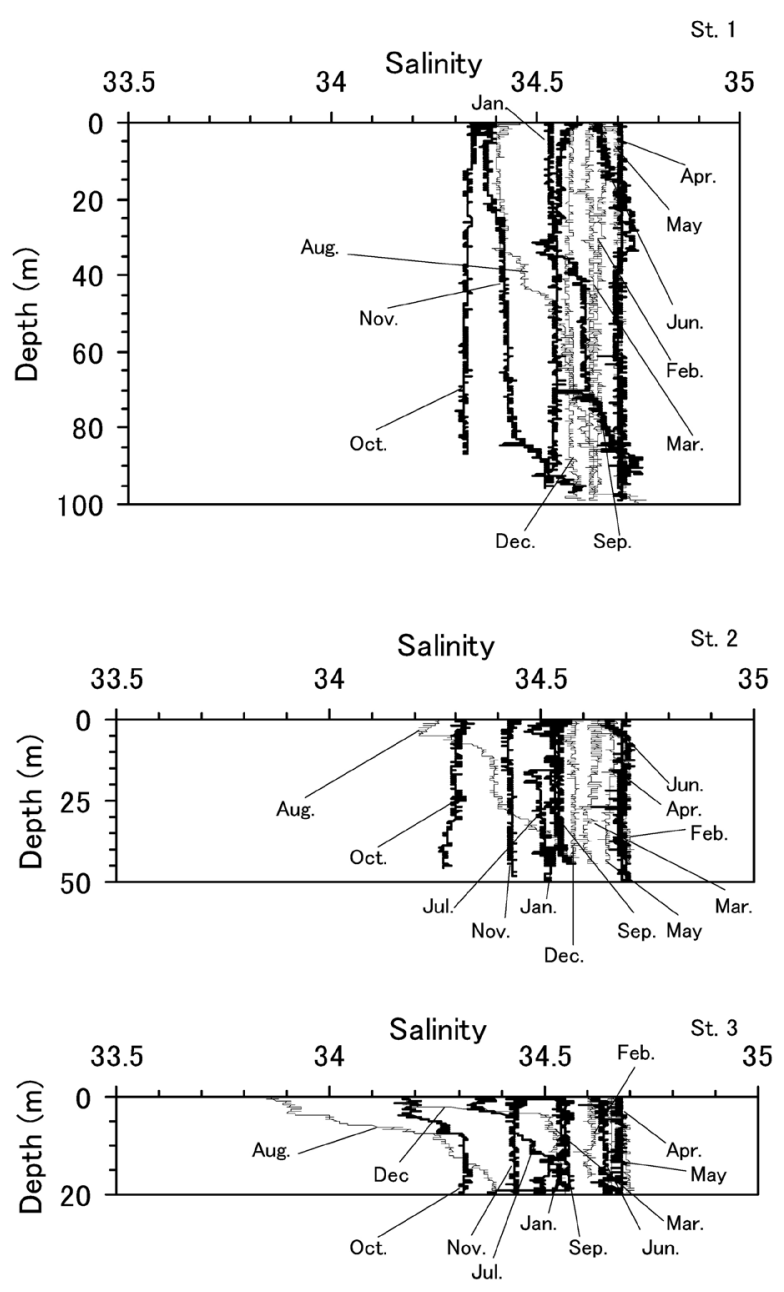

図 3 沖合域の調查点における塩分の鉛直プロ ファイル

Fig. 3 Vertical profiles of the salinity from three offshore sites

された。

宮良川河口及び沖合域（St.1，2，3）における表 面水の分析結果をそれぞれ Appendix A， B に示し た。宮良川河口に拈り塩分は, 概ね 0 から 32 程 度まで大きく変動した。また, ケイ酸塩, リン酸塩, 溶存カドミウムの濃度変動は塩分同様に著しく, そ れぞれ概ね $21 \sim 210 \mu \mathrm{M} ， \quad 0.2 \sim 1.5 \mu \mathrm{M} ， \quad 11 \sim 170 \mathrm{pM}$ の範囲であった。沖合域におけるケイ酸塩, リン酸 塩, 溶存カドミウム濃度は熱帯・带熱帯外洋域表層 同様非常に低濃度であり, 一部は検出限界以下で あった。観測值の最大值はケイ酸塩で $7 \mu \mathrm{M}$, リン 酸塩で $0.13 \mu \mathrm{M}$, 溶存カドミウムで $32 \mathrm{pM}$ 程度で あった。 


\section{考察}

\section{沖合域における水温・塩分の分布特性}

沖合域（St. 1，2，3）における表面水温及び宮良 川河口近傍の真栄里における各月の日平均気温（気 象庁ホームページ http://www.jma.go.jp/jma/index. html より）の周年変動を Fig. 4 に示した。図中の 各月の日平均気温值は便宜上各月の観測日と同日に プロットした。表面水温は各観測点間で大きな違い はなく 7 月から 10 月にかけて概ね $28^{\circ} \mathrm{C}$ 以上を示 し，12月から 4 月にかけて $25^{\circ} \mathrm{C}$ 以下で推移した。 各月の日平均気温は 2006 年 1 月が $18.9^{\circ} \mathrm{C}$ の最低で 2007 年 7 月に $29.9^{\circ} \mathrm{C}$ の最高值を示した。表面水温 が下降する場合には気温の下降に追随する傾向でそ のパターンに遅れを生じる。これは表面水の冷却に 伴う鉛直混合による下層の高温水との混合により表 面水が温められ, 水柱全体が冷却されるまでに時間 を要することに起因すると考えられる。また, 表面 水温の最低值は日平均気温のそれよりも高い。一 方, 表面水温の上昇時にはこの混合過程がなくその パターンは気温とほぼ連動し, 観測された最高水温 は日平均気温の最高值とほぼ一致した。以上沖合域 における表面水温の変動パターンは, 気温の変動パ ターンと連動しているものと考えられ, 調査海域の 鉛直的な水温変動パターンも気温の変動に影響され るものと考えられる。

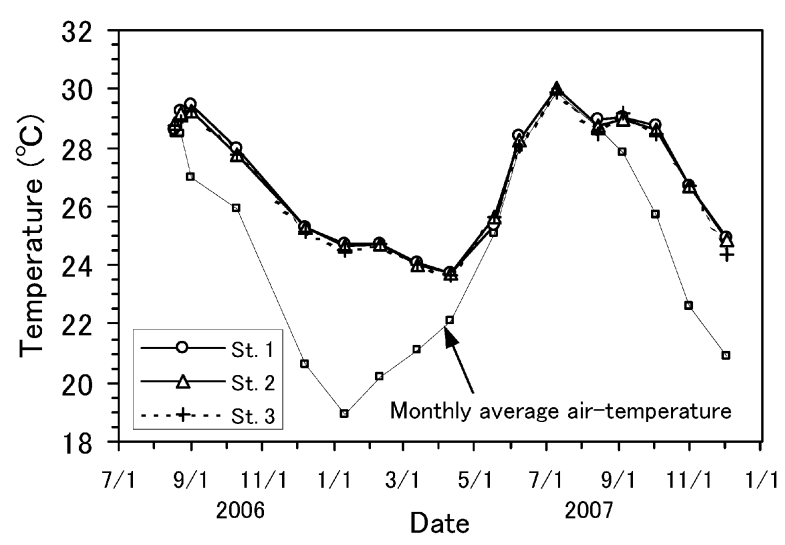

図 4 沖合域の 3 調查地点における表層水温の季節 変化と石垣市真栄里 (図 1 参照) に招ける月平均気温

Fig. 4 Seasonal variations of the sea-surface temperature from three offshore sites and monthly average air-temperature at Maezato, Ishigaki, Okinawa (shown in Fig. 1)
沖合域の塩分の鉛直分布は概ね，1月から 4 月ま では 34.5 から 34.7 までの上昇傾向, 6 月から 10 月 までは 34.6 から 34.4 付近までの低下傾向, その後 再び増加傾向が認められた。Fig. 5 に真栄里におけ る 2006 年 7 月から 2007 年 12 月までの各月毎の降 水量（気象庁ホームページ http://www.jma.go.jp/ jma/index.html より）を示した。1月から 4 月は比 較的降水量が少なく, つまり定性的には河川からの 淡水流出が減少し, その結果沖合域の塩分が増加す る方向であり，6月から 10 月までは降水量の増加 に伴う淡水流出により希釈される方向であると考え られる。つまり，沖合域における塩分の季節的な変 動は, 定性的には降雨の影響による沖合域への淡水 流出を反映しているものと考えられる。本研究期間 内の 2007 年 8 月には調查日の前・前々日に真栄里 でそれぞれ $22 \mathrm{~mm}, 63 \mathrm{~mm}$ の比較的多い降雨が記 録された。8月の塩分観測結果では, 水深 $20 \mathrm{~m}$ 程 の St. 3 を含めて 40 から $50 \mathrm{~m}$ 以浅では特に表面へ 向かっての塩分低下傾向が著しい（Fig. 3)。これは 降雨による増水のために一時的に宮良川からの淡水 流出が多くなったことを意味すると考えられる。こ のことは，宮良川河口に近い調查点（St. 3）ほど表 面塩分の低下が著しい傾向にあることからも淡水流 出の影響が伺える。このような降雨の影響は季節的 な変動とは別の突発的な事象として捕らえられ, 特 に表層塩分の一時的な減少として現れると考えられ る。また水温分布特性は特に表面水温の変動に限る と, 8 月の降雨の影響は塩分ほど顕著には現れてお らず (Fig. 2), 各時期における水温特性を示してい るものと考えられる。宮良川からの流出水の影響と いう観点をも考慮し, 表面水の塩分・水温による海 域特性の把握を試みた。

沖合域に扔ける表面水の塩分と水温の関係を Fig. 6 にプロットした。プロット点を水温分布に基づい て，便宜的に 12-5月，6-10月，及び 11 月と 3 グ ループに分け，各グループを点線で囲み区分した。 12-5 月は低水温・高塩分側を反映し, その後 6-10 月は気温上昇に伴う高水温傾向が認められ，また, この時期の塩分は比較的多い降水量の影響を受け, 低塩分側をも含めた広範囲に分布した。11月は水 温の下降及び塩分の上昇傾向を示し, 前記二つのグ ループの中間的な位置にあると考えられる。このこ とは季節的な降水量の増加に伴う宮良川からの淡水 流出, 及び気温の変動が調查海域, 特に表面水の水 


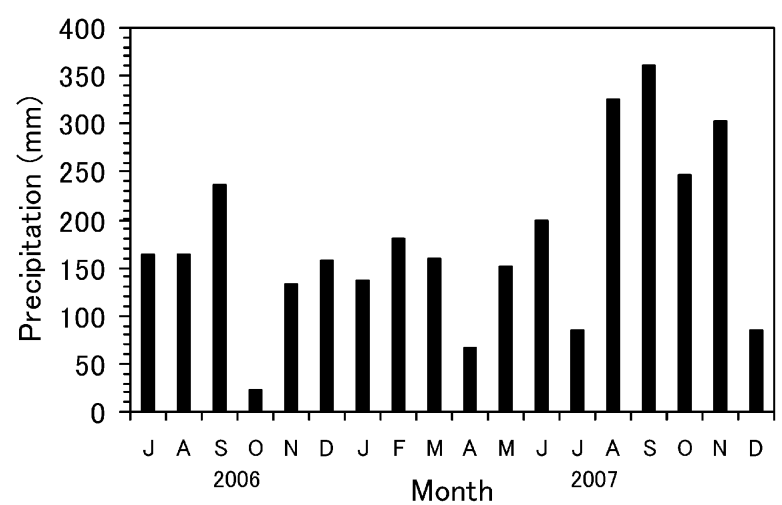

図 52006 年 7 月から 2007 年 12 月にかけての石 垣市真栄里における降水量

Fig. 5 Monthly precipitation at Maezato, Ishigaki, Okinawa from July 2006 to December 2007

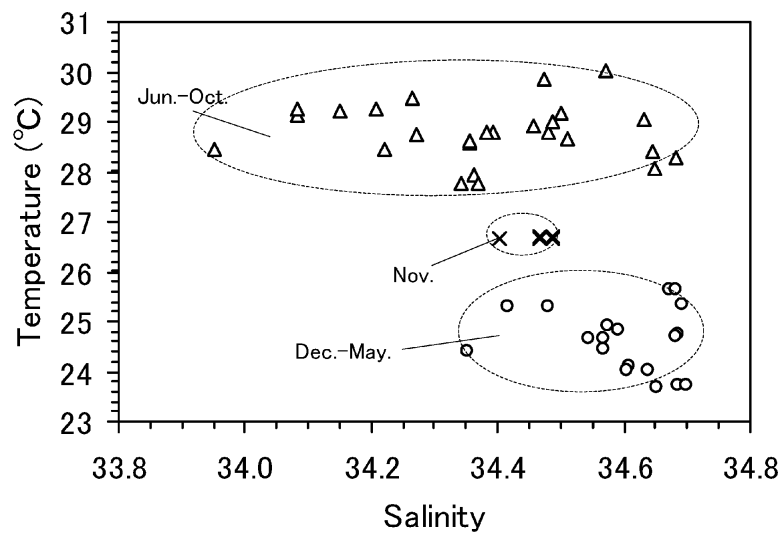

図 6 沖合域の 3 観測点における水温一塩分のダイ アグラム。データを 3 つのグループ（12 月-5 月， 6 月-10月，11月）に分け，それぞれを楕円で囲んで 示す

Fig. 6 T-S diagram of three offshore sites. For the sake of convenience, the plotted points are classified into three groups: December-May, June-October, and November. Each group is surrounded by a dotted ellipse

温・塩分特性に大きく影響を与えているものと考え られる。

\section{宮良川河口におけるケイ酸塩・リン酸塩・溶存カド ミウム}

宮良川河口における塩分を, 真栄里で観測された 降水量に対してプロットした（Fig. 7)。なお，降水 量データは試料採取当日及び前日の 2 日間の值を用 い(気象庁ホームページ http://www.jma.go.jp/jma/

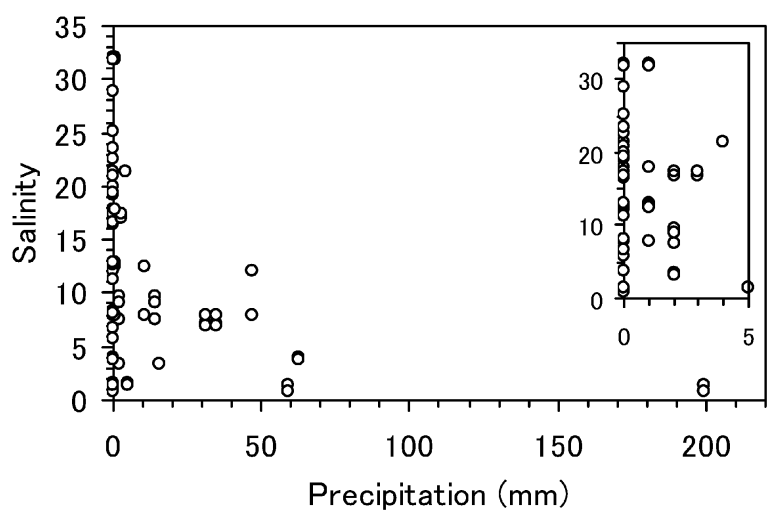

図 7 石坦市真栄里の降水量に対する河口域の塩 分。中の囲みに降水量の少ない場合をスケールを変 えて示す

Fig. 7 Plot of salinity from the river mouth site against precipitation at Maezato, Ishigaki, Okinawa with insert graph for the low range of precipitation at expanded scale

index.html より), 降水量が $5 \mathrm{~mm}$ 以下の結果を挿 入グラフで示した。降水量は最大で $200 \mathrm{~mm}$ 程度が 観測されたが，概ね $10 \mathrm{~mm}$ を超えると観測された 塩分は 15 を超えることはなく，降水の影響による 塩分の低下を示唆するものと考えられる。一方降水 の影響がほとんどない時（概ね $5 \mathrm{~mm}$ 以下）であっ ても 1 程度の低塩分が観測され, かつ最大 32 程度 と大きく変動した。これは試料採取日の採取時間が 概ね同時刻であり，各採取日間の潮位等の条件が一 致していなかったために, 河川水が潮汐の影響を受 け様々な割合で海水と混合した結果であると考えら れる。河口における塩分変動の要因となる河川水 · 海水の混合は, 河川水の流量や試料採取時の潮位, 上げ潮・下げ潮の状況等が複雑に影響するものと考 えられる。本調査では降水の影響は認められるが, 宮良川河口において観測された塩分変動は主に潮汐 の影響によるものと考えられる。

宮良川河口におけるケイ酸塩, リン酸塩, および 溶存カドミウムを塩分に対して Fig. 8 にプロット した。各グラフ中の点線で囲った部分は後に Fig. 9 で示す沖合域における結果である。ケイ酸塩（Fig. 8a）は概ね直線関係を示し，宮良川河口では見かけ 上単純希䣋混合に近い挙動であると言える。これは 生物, 特に珪藻類の生産が活発ではない時期の河口 域における報告とほほ一致する（Kamatani and Takano 1984; Mukadam et al. 2006)。一般的に河 口域や沿岸海域では, ケイ酸塩は陸域からの供給, 
生物生産活動による取り込み, 水柱内での生物起源 ケイ素の溶解や海底からの供給によりその濃度が規 定される（D’Elia et al. 1983）。しかしながら水の流 動が大きな水域では, 生物生産活動等の影響が水の 動きに打ち消され, 観測上は濃度変動が現れないこ とも報告されている (Aguilar-Islas and Bruland 2006）。宮良川（河口）においては生物生産活動に よる取り込みや川底からの供給等が無視できるかこ れらのバランスがとれている, 又は河口域における 水の流動の効果が卓越しこれらを打ち消すために, 見かけ上希釈混合を示すと考えられる。リン酸塩 （Fig. 8b）は塩分 0 10 程度まで緩やかに濃度が上 昇し，その後低下傾向であった。塩分に対するプ ロットではケイ酸塩のような希釈混合ではなく, 上 に凸の曲線傾向を示した。これは塩分増加に伴う懸 濁粒子からの溶出の効果が大きいことに起因する結 果である考えられ, 同様の結果は長江やアマゾン川 河口域においても報告されている (Edmond et al. 1981, 1985)。溶存カドミウム（Fig. 8c）はリン酸塩 よりもさらに希釈混合パターンを示さず, 塩分 20 程度まで上昇傾向であった。溶存カドミウムは Comans and van Dijk（1988）が報告している様に, 塩分増加に伴う懸濁粒子表面からの溶出が著しく, 一般に河口域において本研究と同様に塩分 20 付近 を最大とする上に凸の傾向が報告されている (Edmond et al. 1985; Audry et al. 2007)。宮良川に おいては量的にも時期的にも不規則に供給されると 思われる懸濁粒子との相互作用により, Fig. 8c で 示されるようにプロット点は上に凸の傾向が認めら れ，さらにプロット点は全体的に大きくばらつくも のと考えられる。

沖合域におけるケイ酸塩・リン酸塩・溶存カドミウム 沖合域におけるケイ酸塩, リン酸塩, 溶存カドミ ウム濃度を塩分に対してプロットした（Fig. 9）。図 中の直線は, 沖合域における結果に宮良川河口にお ける塩分 31.7 以上の 3 点（河口で観測された塩分 の最大值）を加えたものの回帰直線である。沖合域 において 3 成分ともにプロットは観測点毎にはまと まらず，全体的に散らばる傾向を示した。しかしな がら, 回帰直線よりばらついてはいるものの, 概ね 河口と外洋域の值をエンドメンバーとした希釈混合 を示していると判断される。つまり, 調査期間内で 河口域において観測された塩分の最大值（約 32）
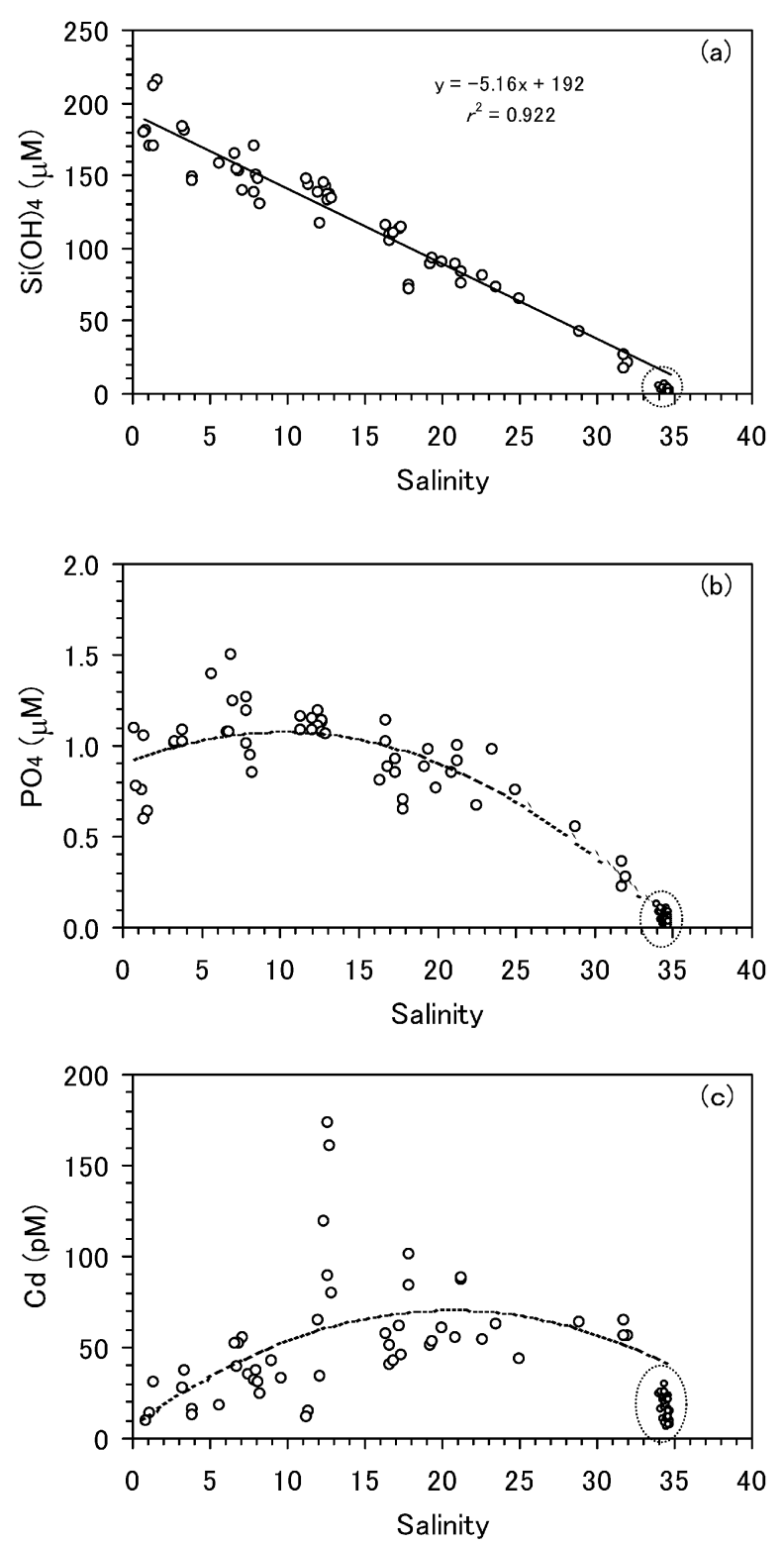

図 8 河口域の塩分に対するケイ酸塩, リン酸塩, 及び溶存カドミウム濃度。沖合域の観測点のデータ (図 9 参照) を楕円で囲んで示す。図 $8 \mathrm{a}$ の直線は回 帰直線を示す $(y=-5.16 \mathrm{x}+192)$ 。図 $8 b, c$ におい て, データの傾向を二次曲線で示す

Fig. 8 Plot of $\mathrm{Si}(\mathrm{OH})_{4}(\mathrm{a}), \mathrm{PO}_{4}$ (b), and $\mathrm{Cd}(\mathrm{c})$ against the salinity from the river mouth site. In each panel, a dotted ellipse surrounds the data from offshore sites (shown in Fig. 9). A straight line in Fig. 8a is the regression line for the river mouth site plots $(y=-5.16 x+192)$. In Fig. 8b, c, convex curves seemed to be regressive, and quadratic curves are illustrated for the sake of convenience

を宮良川河口における塩分の最大值であると仮定す ると,この值と外洋域の值との混合により沖合域の 

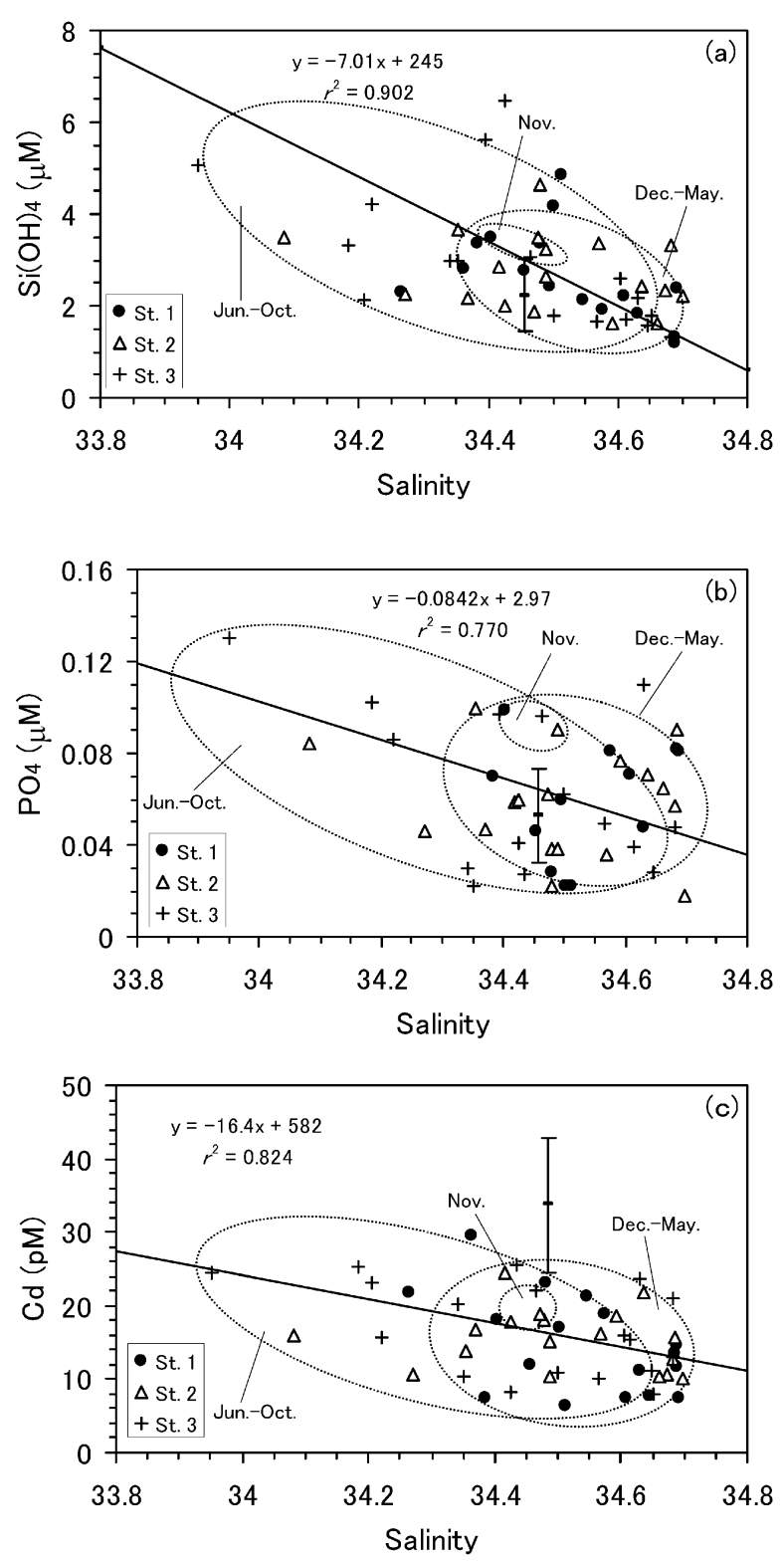

図 9 沖合域の塩分に対するケイ酸塩, リン酸塩, 及び溶存カドミウム濃度。図中の直線は, 沖合域に おける結果に宮良川河口における塩分 31.7 以上の 点を加えたものの回帰直線である。各図において、 図 6 で示すようにデータを 3 つのグループ (12月 -5 月， 6 月-10月，11月）に分け，それぞれを楕円 で囲んで示す。誤差棒は標準偏差を示す

Fig. 9 Plots of $\mathrm{Si}(\mathrm{OH})_{4}(\mathrm{a}), \mathrm{PO}_{4}$ (b), and $\mathrm{Cd}$ (c) against the salinity in surface seawater from three coastal sites. The straight line is the regression line for the plots of offshore and river mouth sites (data with salinity over 31.7$)$. In each panel, plotted points are classified into three groups defined in Fig. 6 (December-May, June-October, and November), and a dotted ellipse surrounds each group. The error bar represents the standard deviation
濃度が概ね決定されると考えられる。これは低緯度 海域における比較的小さな生物生産活動に起因し, 植物プランクトン等の生物による取り込みや分解 . 再生が観測上現れないものと考えられる。それぞれ の罒中のプロット点を水温・塩分特性より区分した グループ毎に点線で囲んだが，12-5 月が高塩分側, 6-10月が低塩分側的に位置している。つまり，610 月は淡水による希釈効果が 12-5 月よりも比較的 大きいことを示している。このことは, 周年を通し て 3 成分の濃度変動そのものは小さいが, 季節によ るこれら 3 成分の起源の違いを示唆するものであ る。とりわけ6-10月には宮良川からの流出水起源 が比較的多く沖合域を占めていることになり, この 時期には同河川の調査海域への影響が大きなものと 考えられ，時期の違いにより宮良川の影響に違いが あることが示された。

本研究において観測された沖合域の 3 成分それぞ れの濃度レベルは, サンゴ礁近接海域の報告值と概 ね一致し (Shen et al. 1987; Charpy-Roubaud et al. 1990; Ayukai 1993; Gast et al. 1999; Esslemont 2000), 調査海域表面水中の栄養塩等は現時点では 人為的污染の影響をあまり受けていないものと考え られる。石垣島周辺のサンゴ礁域における報告例で は, 石西礁湖表面水のケイ酸塩, リン酸塩はそれぞ れ $2.0 \mu \mathrm{M}, \quad 0.08 \mu \mathrm{M}$ 程度（黒山ら 2000), 石垣島北 部の浦底湾ではケイ酸塩, リン酸塩, 溶存カドミウ ムはそれぞれ 1〜 50 $\mu \mathrm{M}, \quad 0.016 〜 0.31 \mu \mathrm{M}, \quad 5 \sim 80$ pM 程度である（Abe 2007a,b）。調査海域である沖 合域における 3 成分の観測結果はこれらとほぼ同程 度か低濃度であり，特に宮良川からの供給による高 濃度レベルを維持しているわけではない。調査海域 近傍の海水流動構造は平均的に西側へ向かう傾向で あり, 日本最大のサンゴ礁海域である石西礁湖周辺 へ輸送され, その一部は礁湖内に流入するものと考 えられている（灘岡ら 2003; 三井ら 2004; 田村ら 2005)。サンゴ生育と栄養塩濃度の関係は中野 (2002) の総括中にもあるように, リン酸塩がカル シウム骨格形成に阻害作用を及ぼすとされ,

Simkiss（1964）は環境水中に $10 \mu \mathrm{M}$ 以上で炭酸力 ルシウムの結晶化を阻害すると報告している。我が 国におけるチッソ・リン等の富栄養化とサンゴの生 育状況の関係に関する報告例は多くはないが，松川 （1998）は沖縄県下においてサンゴの生育は底質状 態にも影響を受けるが, リン酸塩が概ね $0.2 \mu \mathrm{M}$ を 
超えると生育の悪化及び海藻群落が繁茂し始めるこ とを報告している。本調査における沖合域ではリン 酸塩が最大で $0.13 \mu \mathrm{M}$ 程度であり, 仮にこのまま礁 湖内へ流入すると仮定しても，松川（1998）の報告 や石垣島周辺のサンゴ礁域の観測值から判断する と, サンゴ礁生態系への負の影響は非常に小さなも のであると考えられる。また導入部でも述べたが, 有害微量金属であるカドミウムは受精への影響が認 められる濃度は $10 \mu \mathrm{M}$ 程度であり (Reichelt-Brushett and Harrison 2005), 本調査での最大濃度は $32 \mathrm{pM}$ 程度であるという結果より, 調查海域のカドミウム 濃度は現在のところサンゴの受精には全く影響を与 えるレベルではないと判断される。よってカドミウ ムの結果のみではあるが, 調查海域はサンゴ礁生態 系に影響を与えるほど重金属污染は進行していない ものと推測される。

\section{結論}

石垣島宮良湾沖合域の海域特性は, 本研究の調查 期間内ではあるが，水温・塩分より概ね 12-5 月の 低水温・高塩分傾向, 6-10月の高水温・広範囲な 塩分分布, 及び 11 月の中間的な傾向を示す周年変 動が認められた。宮良川河口における調查の結果, 塩分は潮汐の影響を強く受け, 概ね 0 から 32 程度 と大きく変動した。また, ケイ酸塩, リン酸塩, 及 び溶存カドミウム濃度も塩分同様に大きく変動し, ケイ酸塩は概ね希釈混合, リン酸塩及び溶存カドミ ウムは懸濁粒子との相互作用により, 塩分に対して プロットすると上に凸の曲線となった。沖合域にお けるこれら 3 成分の濃度レベルは季節的には大きな 変動は認められないが, 宮良川河口の挙動とは不連 続な河口域に端を発する見かけ上希釈混合に近い挙 動をしていることが示され，河口より概ね 2〜 $4 \mathrm{~km}$ 沖合にも河川の影響が及ぶことが示唆された。さら に, 沖合域では 6-10月に河川水の影響が比較的強 く, 時期毎に 3 成分の宮良川からの寄与に違いがあ ることが示された。また, 沖合域の海水が海水交換 で隣接するサンゴ礁内へ流入した場合でも, 調査海 域で得られたリン酸塩やカドミウム濃度は現在のと ころ富栄養や重金属污染等の兆候はなく, 隣接する サンゴ礁生態系への影響は小さいものと考えられる。

\section{謝辞}

フィールド調查及び試料採取において西海区水産 研究所石垣支所職員にご協力を頂いた。記して謝意 を表す。

\section{引用文献}

Abe K (2001) Cd in the western equatorial Pacific. Mar Chem 74: 197-211

Abe K (2007a) Concentration level of dissolved cadmium and its variation in surface seawater of Urasoko Bay, Ishigaki Island. J Oceanogr 63: 341347

Abe K (2007b) Variation in the phosphate concentration in surface seawater of Urasoko Bay, Ishigaki Island. Galaxea, JCRS 8: 117-122

Aguilar-Islas AM, Bruland K (2006) Dissolved manganese and silicic acid in the Columbia river plume: A major source to the California current and coastal waters off Washington and Oregon. Mar Chem 101: 233-247.

Audry S, Blanc G, Schäfer J, Guérin F, Masson M, Robert S (2007) Budgets of Mn, Cd and Cu in the macrotidal Gironde estuary (SW France). Mar Chem 107: 433-448

Ayukai T (1993) Temporal variability of the nutrient environment on Davies Reef in the central Great Barrier Reef, Australia. Pac Sci 47: 171-179

Boyle EA, Edmond JM (1977) Determination of copper, nickel, and cadmium in seawater by APDC chelate coprecipitation and flameless atomic absorption spectrometry. Anal Chem Acta 91: 189197

Charpy-Roubaud CJ, Charpy L, Cremoux JL (1990) Nutrient budget of the lagoonal waters in an open central south Pacific atoll (Tikehau, Tuamotu, French Polynesia). Mar Biol 107: 67-73

Comans RNJ, van Dijk CPJ (1988) Role of complexation processes in cadmium mobilization during estuarine mixing. Nature 336: 151-154

Coles SL, Ruddy L (1995) Comparison of water quality and reef coral mortality and growth in 
southeastern Kaneohe Bay, Oahu, Hawaii, 1990 to 1992, with conditions before sewage diversion. Pac Sci 49: 247-265

D’Elia CF, Nelson DM, Boynton WR (1983) Chesapeake Bay nutrient and plankton dynamics: III. The annual cycle of dissolved silicon. Geochim Cosmochim Acta 47: 1945-1955.

Edmond JM, Boyle EA, Grant B, Stallard RF (1981) Chemical mass balance in the Amazon Plume I : the nutrients. Deep-Sea Res 28: 1339-1374

Edmond JM, Spivack A, Grant BC, Ming-Hui H, Zexiam C, Sung C, Xiushau Z (1985) Chemical dynamics of the Changjiang estuary. Cont Shelf Res 4: $17-36$

Esslemont G (2000) Heavy metals in seawater, marine sediments and corals from the Townsville section, Great Barrier Reef Marine Park, Queensland. Mar Chem 71: 215-231

Gast GJ, Jonkers PJ, van Duyl FC, Bak RPM (1999) Bacteria, flagellates and nutrients in island fringing coral reef waters: Influence of the ocean, the reef and eutrophication. Bull Mar Sci 65: 523538

Kamatani A, Takano M (1984) The behavior of dissolved silica during the mixing of river and sea waters in Tokyo Bay. Estuar Coast Shelf Sci 19: $505-512$

黒山順二, 豊田孝義, 筒井浩之, 中島敏光 (2000) 石西礁湖における礁斜面の環境因子と台風の影響 に関する研究. 海洋科学技術センター試験研究報 告 40: 47-54

松川康夫（1998）サンゴ礁の環境基準を求めて。中 央水産研究所ニュース 20: 5-6

三井 順, 灘岡和夫, 鈴木庸壱, 熊谷 航, 石神健 二, 波利井佐紀, Paringit EC, 田村 仁, 安田 仁奈, 飯塚広泰, 濱崎克哉, 木村 匡, 上野光弘 （2004）沖縄・石西礁湖における海水流動および 濁質・熱・サンゴ幼生輸送特性解明のための総合 観測と解析．海岸工学論文集 51: 1055-1059

Mukadam KM, Yonaha T, Ali VS, Tokuyama A (2006) Dissolved aluminum and silica released on the interaction of Okinawa subtropical red soil and seawater at different salinities: Experimental and field observations. Geochem J 40: 333-343
仲宗根一哉, 比嘉榮三郎, 満本裕彰, 大見謝辰男 （1998）沖縄県に打ける赤土当年間流出量（第 2 報）一赤土当流出防止条例施行後の年間流出量の 推算一. 沖縄県衛生環境研究所報 32: 67-72

Nakamori T, Suzuki A, Iryu Y (1992) Water circulation and carbon flux on Shiraho coral reef of the Ryukyu Islands, Japan. Cont Shelf Res 12: 951970

中野義勝 (2002) 造礁サンゴの環境負荷への生理生 態的反応に係わる研究の概要. 中森 享編 日本 におけるサンゴ礁研究 I. 日本サンゴ礁学会,

東京, pp 43-49

灘岡和夫（2001）サンゴ礁海域の環境水理。ながれ 20: $375-383$

灘岡和夫, 三井 順, 濱崎克哉, 波利井佐紀, 田村 仁, 鈴木庸壱 (2003) 沖縄・石西礁湖における海 水流動構造および濁質・淡水・熱輸送特性に関す る現地観測. 海岸工学論文集 50: 1036-1040

灘岡和夫, 二瓶康雄, 熊野良子 (1999) 高解像度水 深マップを用いたサンゴ礁海域の流動シミュレー ション。 海岸工学論文集 46: 1186-1190

大見謝辰男 (1996) 赤土堆積がサンゴに及ぼす影響. 沖縄県衛生環境研究所報 30: 79-86

Reichelt-Brushett AJ, Harrison PL (2005) The effect of selected trace metals on the fertilization success of several scleractinian coral species. Coral Reefs 24: 524-534

Shen GT, Boyle EA, Lea DW (1987) Cadmium in corals as a tracer of historical upwelling and industrial fallout. Nature 328: 794-796

Simkiss K (1964) Phosphates as crystal poisons of calcification. Biol Rev 39: 487-505

Strickland JD, Parsons TR (1972) A practical handbook of seawater analysis (2nd ed). Fish Res Board Canada 167

田村 仁, 灘岡和夫, 鈴木庸壱, 宮澤泰正, 三井 順（2005）沖縄・石西礁湖自然再生計画立案のた めの熱・物質輸送数值シミュレーション. 海岸工 学論文集 52: 1161-1165

2008 年 3 月 10 日受領 2008 年 8 月 31 日受理

(C) 日本サンゴ礁学会 
付録 A 宮良川河口域の観測点における分析結果

Appendix A Brackishwater analysis results (Miyara Rver mouth)

\begin{tabular}{|c|c|c|c|c|}
\hline Date & Salinity & $\mathrm{Si}(\mathrm{OH})+(\mu \mathrm{M})$ & $\mathrm{PO}_{4}(\mu \mathrm{M})$ & $\mathrm{Cd}(\mathrm{pM})$ \\
\hline \multirow[t]{3}{*}{$2006 / 8 / 24$} & 7.528 & 165 & 1.47 & 35.4 \\
\hline & 9.613 & 136 & 1.41 & 32.6 \\
\hline & 8.998 & 136 & 1.49 & 42.2 \\
\hline \multirow{2}{*}{$9 / 1$} & 7.871 & 170 & 1.27 & - \\
\hline & 12.474 & 142 & 1.19 & - \\
\hline \multirow[t]{3}{*}{$12 / 12$} & 12.737 & 136 & 1.13 & 161 \\
\hline & 12.632 & 137 & 1.14 & 173 \\
\hline & 12.417 & 144 & 1.11 & 119 \\
\hline \multirow[t]{3}{*}{$12 / 14$} & 7.065 & 139 & 1.24 & 55.1 \\
\hline & 7.858 & 138 & 1.19 & 31.8 \\
\hline & 6.847 & 153 & 1.50 & 52.6 \\
\hline \multirow[t]{2}{*}{$2007 / 1 / 10$} & 5.669 & 159 & 1.39 & 18.6 \\
\hline & 12.055 & 139 & 1.15 & 64.8 \\
\hline \multirow[t]{2}{*}{$2 / 9$} & 7.938 & 150 & 1.01 & 36.9 \\
\hline & 12.086 & 117 & 1.09 & 34.4 \\
\hline \multirow[t]{2}{*}{$3 / 13$} & 1.182 & 170 & 0.76 & 13.3 \\
\hline & 0.818 & 181 & 0.77 & 9.73 \\
\hline \multirow[t]{2}{*}{$4 / 11$} & 3.371 & 181 & 1.01 & 37.6 \\
\hline & 3.292 & 183 & 1.02 & 27.5 \\
\hline \multirow[t]{2}{*}{$4 / 20$} & 11.353 & 144 & 1.16 & 15.2 \\
\hline & 11.264 & 147 & 1.08 & 12.1 \\
\hline \multirow[t]{2}{*}{$5 / 17$} & 31.970 & 21.3 & 0.28 & 56.6 \\
\hline & 31.787 & 17.7 & 0.22 & 64.6 \\
\hline \multirow[t]{2}{*}{$5 / 18$} & 12.673 & 133 & 1.07 & 89.8 \\
\hline & 12.873 & 134 & 1.06 & 80.0 \\
\hline \multirow[t]{5}{*}{$5 / 24$} & 25.038 & 64.6 & 0.76 & 43.4 \\
\hline & 31.801 & 26.8 & 0.36 & 56.6 \\
\hline & 17.309 & 113 & 0.93 & 62.2 \\
\hline & 22.579 & 80.6 & 0.67 & 54.3 \\
\hline & 28.853 & 42.7 & 0.55 & 64.1 \\
\hline \multirow[t]{4}{*}{$5 / 25$} & 16.369 & 116 & 0.81 & 57.0 \\
\hline & 20.891 & 89.7 & 0.85 & 55.4 \\
\hline & 19.946 & 89.8 & 0.77 & 60.6 \\
\hline & 23.454 & 73.0 & 0.98 & 63.2 \\
\hline \multirow[t]{2}{*}{$5 / 28$} & 16.681 & 109 & 1.02 & 40.4 \\
\hline & 16.677 & 105 & 1.14 & 51.2 \\
\hline \multirow[t]{2}{*}{$6 / 8$} & 16.909 & 110 & 0.88 & 42.3 \\
\hline & 17.318 & 114 & 0.85 & 45.7 \\
\hline \multirow[t]{2}{*}{$7 / 10$} & 21.292 & 76.2 & 0.91 & 87.6 \\
\hline & 21.273 & 83.5 & 1.00 & 88.5 \\
\hline \multirow[t]{2}{*}{$7 / 20$} & 19.228 & 89.3 & 0.88 & 51.2 \\
\hline & 19.426 & 93.0 & 0.98 & 52.9 \\
\hline \multirow[t]{2}{*}{$8 / 15$} & 3.874 & 149 & 1.02 & 15.8 \\
\hline & 3.841 & 146 & 1.08 & 12.8 \\
\hline \multirow[t]{2}{*}{$9 / 4$} & 8.239 & 130 & 0.85 & 24.5 \\
\hline & 8.170 & 148 & 0.95 & 30.7 \\
\hline $9 / 19$ & 1.387 & 170 & 1.05 & 30.4 \\
\hline & 0.719 & 179 & 1.10 & - \\
\hline $10 / 3$ & 6.680 & 165 & 1.07 & 52.6 \\
\hline & 6.732 & 154 & 1.07 & 39.6 \\
\hline $11 / 1$ & 17.891 & 74.2 & 0.70 & 11.4 \\
\hline & 17.836 & 71.8 & 0.65 & 9.36 \\
\hline $12 / 3$ & 1.564 & 216 & 0.63 & 19.3 \\
\hline & 1.410 & 211 & 0.60 & 18.8 \\
\hline
\end{tabular}

*"-" denotes no data. 


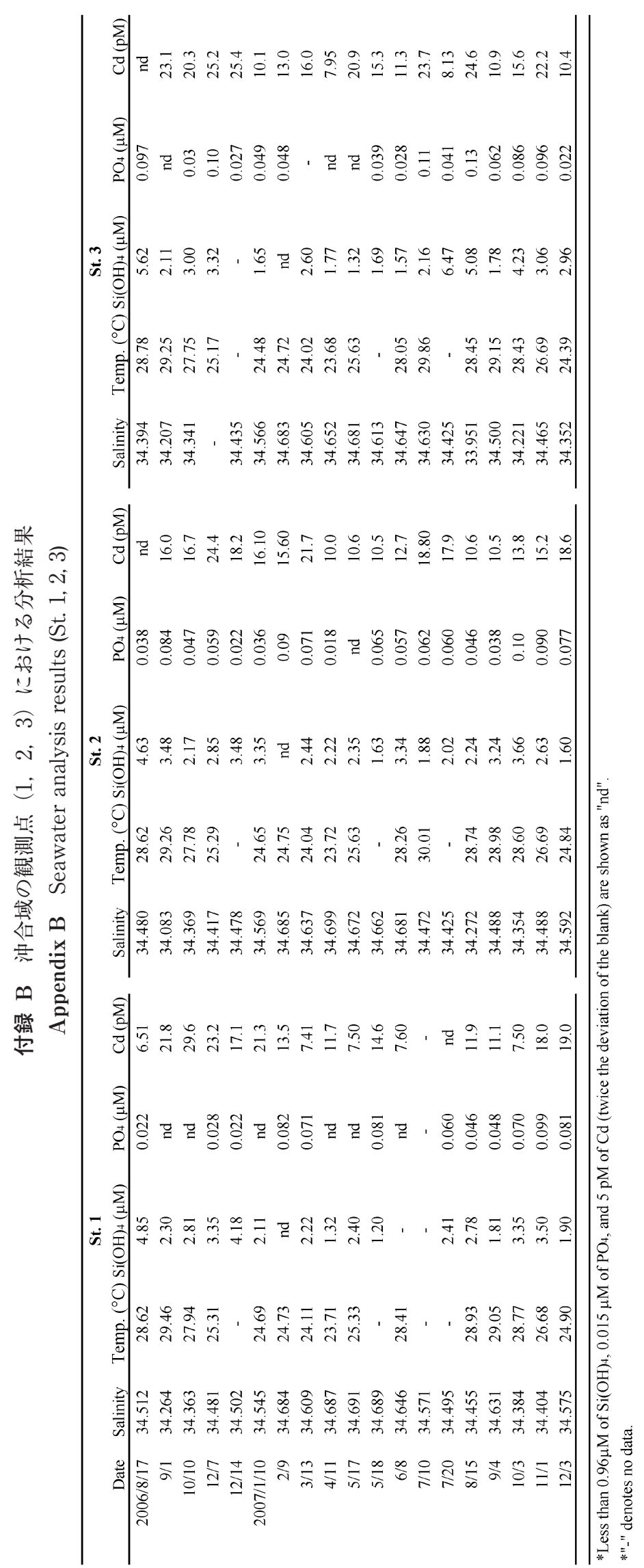


Original paper

\title{
On the silicate, phosphate, and dissolved cadmium in the surface water in the coastal zone off Miyara River, Ishigaki Island
}

\author{
Kazuo ABE* and Kouki FUKUOKA \\ Ishigaki Tropical Station, Seikai National Fisheries Research Institute, Fisheries Research Agency, 148-446 \\ Fukai-Ota, Ishigaki, Okinawa 907-0451, Japan \\ * Corresponding author: K. Abe \\ E-mail: abek@fra.affrc.go.jp \\ Communicated by Hiroya Yamano (Environment and Conservation Editor)
}

\begin{abstract}
From August 2006 to December 2007, the concentrations of silicate $\left(\mathrm{Si}(\mathrm{OH})_{4}\right)$, phosphate $\left(\mathrm{PO}_{4}\right)$, and dissolved cadmium $(\mathrm{Cd})$ were monitored in the surface water at three stations in the coastal zone off Miyara River, Ishigaki Island and the mouth of the Miyara River. The distances of offshore stations from the shoreline were approximately 1800, 2700, and $3900 \mathrm{~m}$, respectively. From the results of the surface-water temperature and salinity, offshore sites were classified into three seasonal water mass groups, namely, from December to May, June to October, and November. From December to May, the surface-water temperature was relatively low, and the surface-water salinity was relatively high. On the other hand, from June to October, the water temperature increased, and the salinity scattered in a wide range towards the low salinity zone due to the influence of relatively large precipitation in this season. In November, the $T-S$ diagram intermediated between those two groups. The concentrations of $\mathrm{Si}(\mathrm{OH})_{4}, \mathrm{PO}_{4}$, and $\mathrm{Cd}$ at the offshore sites were extremely small (the maximum concentrations observed were $7 \mu \mathrm{M}, 0.13 \mu \mathrm{M}$, and $32 \mathrm{pM}$, respectively) and showed little seasonal variations, suggesting that the influences such as eutrophication and heavy metal pollution upon the adjacent coral reef ecosystem could not be recognized in the present day.
\end{abstract}

Keywords: silicate, phosphate, dissolved cadmium, coastal zone, ishigaki island

Received: 10 March 2008/Accepted 31 August 2008

(C) Japanese Coral Reef Society 